\title{
The Effect of Concept Attainment Model and Mathematical Logic Intelligence on Introductory Chemistry Learning Outcomes
}

\author{
Aceng Haetami*, Maysara², Eka Cahyana Mandasari iD \\ ${ }^{123}$ Department of Chemistry Education, Halu Oleo University, Kendari, Indonesia \\ *Corresponding author: acenghaetami@uho.ac.id
}

\begin{abstract}
The purpose of this study was to determine the effect of concept attainment model and mathematical logic intelligence on the learning outcomes of introductory chemistry. This research was conducted using a quasi-experimental method with a $2 \times 2$ treatment by level design. Total samples are 56 students selected by random sampling. Data analysis used ANOVA with a significance of 0.05 . The results showed that: (1) The introductory chemistry learning outcomes of students taught with the concept achievement learning model are higher than those acquainted with the direct learning model; (2) There is the effect of the interaction between learning models and mathematical logic intelligence to study introductory chemistry learning outcomes; (3) The student of learning outcomes taught with the concept attainment model are higher than those taught with the direct learning model for groups of students high logicalmathematical intelligence; (4) The student of learning outcomes taught with the concept attainment model are lower than those taught with the direct learning model for groups of students low logical-mathematical intelligence. Therefore, the use of the learning model should care to aspects of intelligence of learners, so that the learning objectives are expected to be achieved.
\end{abstract}

Keywords: Concept Attainment Model (CAM); Mathematical Logic Intelligence; Learning Outcomes

History:
Received $\quad: 4$ July 2020
Revised $\quad: 11$ August 2020
Accepted $\quad: 26$ September 2020
Published $\quad: 7$ October 2020

\section{Introduction}

The learning model is a systematic and planned presented educators in implementing the learning process (Khalil \& Elkhider, 2016). The accuracy of the selection of learning models by educators determines the success of achieving learning objectives. Ideally, every educator should be able to choose a model of learning by the characteristics of the topic and learners (Darling-Hammond et al., 2020; Fathurrohman, 2015). However, many educators have difficulty choosing appropriate learning models in the learning process. Educators are generally stuck by the word "transfer of knowledge to learners" (Kawuri et al., 2019; Novitasari et al., 2017). Therefore, in the learning process, educators simply stuffing students with a variety of lecture topic learning more focused on educators, learners just listen and take notes, so learners are passive. It courses not unexpected that the study of students at this time the average low is not as expected.

The low learning outcomes of students as described experienced by students majoring in chemistry education at the Faculty of Teacher Training and Education, Halu Oleo University, especially in introductory chemistry courses. Introductory chemistry courses are 
the focus of the attention of researchers because introductory chemistry is a subject that is the primary fundamental for mastery of different chemical materials. The average result of studying introductory chemistry for the last 3 (three) years was always below 60 . For example, two introductory chemistry courses academic year 2014/2015 the average of 56.71 a distribution value of $5.43 \% ; 51.58 \% \mathrm{~B}$; and $42.99 \% \mathrm{C}$. The academic year 2015/2016 with a mean of 56.63 a value distribution of $4.59 \%$ A; $47.12 \%$ B; $48.29 \%$ C. For the 2016/2017 academic year with a standard of 58.41 with a value distribution of $6.82 \% \mathrm{~A} ; 44.32 \% \mathrm{~B}$; $48.86 \% \mathrm{C}$. It confirms that the learning outcomes of introductory chemistry two have not met expectations and are considered inadequate.

The results of learning introductory chemistry two indeed show that the quality of introductory chemistry teaching at the Faculty of Teacher Training and Education, Halu Oleo University needs to be addressed immediately by referring to the root problems that occur in the classroom. The results of the reflection with the supervisory team for introductory chemistry courses in the Department of Chemistry Education, Faculty of Teacher Training and Education, Halu Oleo University, revealed that the poor learning outcomes for introductory chemistry were due to several things: (1) during this time, chemistry lecturer basis of carrying out learning by using a direct instructional model that focused only at the lecturer, the lecturer gives the material systematically and gradually, the students heard and recorded. There is no interaction in the classroom between teachers and students and between students and students. As a result, student results from year to year increase, (2) Lecture of introductory chemistry do not pay attention to the fact that student abilities vary significantly in terms of both individual potential and student learning experience, (3) introductory chemistry lecturers do not provide training with analysis and synthesis questions so that students' critical thinking skills are less explored. From the results of these reflections can be said that in the learning of introductory chemistry, chemistry professor the Faculty of Education, involving less Halu Oleo university students to active learning, learning motivation consequence they are very low and this, in turn, leads to poor learning outcomes.

The results of analysis by Killian \& Bastas (2015); McCormick et al. (2015) found that learning involves active learners can improve: (1) motivation and interest in learning, (2) interaction between educators and students, (3) critical thinking and problem-solving skills, and (4) student performance. The results of the study indicate that the learning model involves students actively in learning will be able to improve the ability of students to think, work, and be scientific.

One of the offered by researchers that are expected to improve the quality of learning in the classroom to apply a concept attainment model. The concept attainment model is designed to analyze concepts, develop concepts, and acquire concepts and to help students become more effective in learning concepts so that students will find it very easy to understand concepts (Afifah, 2019; Nondo et al., 2016; Situmorang \& Siahaan, 2019). The concept attainment model an efficient model for presenting organized information from a general topic that is easier to understand for each stage of concept development (Siregar, 2012; Rahmi \& Harahap, 2013). Its concept attainment model can provide a way of conveying concepts and clarifying the concepts and train students to become more effective in the control concept, to expect increased student learning outcomes.

There is a significant difference between the concept attainment model (CAM) and the traditional learning model (TM) on student achievement in understanding the concepts of physics and mathematics (Agustin \& Yuliastuti, 2019; Kumar \& Mathur, 2013). Research conducted by Sood (2013), found that the concept attainment model is more effective in improving learning outcomes geometry compared to the conventional learning model. The application of the concept attainment model is more effective than conventional learning which is characterized by: (1) there is an increase in accuracy and skills in writing letters, (2) 
there is an increase in students' ability to identify sounds, and (3) there is increased accuracy and the ability to pronounce letters and words target (Fjortfoft et al., 2014; Hattie \& Donoghue, 2016). Learning achievement of students in the social sciences is explained through the model concept attainment is higher than student achievement is taught through traditional methods (Bhargava, 2016; Kauts \& Kaur, 2019).

In this study, the potential intelligence factors of students are not considered, Moreover it necessary to research the application of the achievement of concepts based on the potential intelligence of students. Suleman (2016), in his research, found that the concept attainment model was useful as a training strategy to train workers about chemical information and health hazards. In contrast, Latchanna \& Swarnalatha (2016) explained that there are significant differences in the average scores of biological sciences post-test between the experimental group (concept attainment model) with a mean of 61.67 and a control group with a mean of 51.67 .

Based on the results of the literature study, it was established that the application of the concept attainment model was very effective in improving student learning outcomes. In the concept attainment model, students require to have the ability to analyze concepts, test, and provide hypotheses (Pérez et al., 2012). Then, the potential intelligence of learners should be identified by the lecturer. Every human being has the potential intelligence called multiple intelligences. Each student has a particular tendency (dominant) from its potential intelligence (Khatabyeh, 2011). One of the potential intelligence of the students is a logicalmathematical intelligence. The basis of logical-mathematical intelligence emphasizes thinking activities that are measured, quantitative, and analytical. In mathematical logic intelligence-based learning emphasizes the ability to reason, learning, thinking in patterns of cause and effect, creating a hypothesis, sought order conceptual or numerical patterns, characterizing something based on cause and effect, grouping, through the process of classification or identification (Barrientos-Fernández et al., 2019; Said, 2017).

In previous studies, the application of learning models does not consider the potential achievement of the concept of student intelligence, Therefore one of the novelties of the research is the application of the concept attainment model considering the potential intelligence of students that mathematical logic intelligence. Based on the description that has been said that it is essential to research whether the concept attainment model and logical-mathematical intelligence affects student learning outcomes.

\section{Materials and Methods}

The method used in this study is the experimental method. The research variables measured in this study include two main variables, namely the independent variable and the dependent variable (Sugiyono, 2008). The dependent variable is the learning outcomes of introductory chemistry, and the independent variable consists of two variables, namely: (a) the treatment variable consisting of the concept attainment model (A1) and the direct learning model (A2), (b) the moderator variable, namely mathematical logical intelligence consisting of intelligence. High mathematical logic (B1) and low mathematical, logical intelligence (B2).

The research phases of the outline are as follows: (a) to perform intelligence tests the logic of mathematics, (b) classify students that have the intelligence logical-mathematical height and intelligence logic of mathematics is low, (c) implementing concept attainment model and learning direct adjusted to the results of sample selection, (d) carry out tests of introductory chemistry learning outcomes.

Sampling this study was conducted by random sampling technique. An overview makes a selection of samples for experimental class and control class of two parallel classes (class A and class B). Before the given treatment, students must first be given an intelligence 
test mathematical logic using a validated instrument. Then from the logical-mathematical intelligence test results sorted from the highest score (ranked top) to lowest score (ranking below). The determination of groups of students who have high and low mathematicallogical intelligence in this study uses the division of $27 \%$ high groups and $27 \%$ low groups as samples (Osterlind, S, 2002).

Based on such distribution, to the experimental class numbering 54 people, was obtained with the intelligence logical-mathematical high and low respectively amounted to $27 \% \times 54=14$ and for the control classes totaling 53 people, was obtained with the intelligence logical-mathematical high and low respectively - each $27 \%$ x 53 people $=14$ people. Thus the experimental class and control class each amounted to 14 people.

Data analysis techniques using descriptive analysis and testing requirements analysis. Descriptive analysis is in the form of finding the average and standard deviation. Whereas for testing the analysis prerequisites in the form of normality test, homogeneity test, analysis in the form of Anova for sample testing. The normality test was carried out using the Liliefors test (Kadir, 2015). Suppose the test results show that $\mathrm{L}_{\text {Count }}<\mathrm{L}_{\text {Table }}$, then the data tested comes from a normally distributed population with a significant level $\alpha=0.05$. The homogeneity test is performed using the F test or the Bartlett test. Suppose the test results show $\mathrm{F}_{\text {Count }}<\mathrm{F}_{\text {Table }}$ or $\chi^{2}$ Count $<\chi^{2}$ Table, then the data on all cells has a homogeneous variance. While testing the hypothesis using ANOVA are presented in Table 1.

Table 1. Treatment Design by Level 2 X 2

\section{Mathematic Logic Intelligence}

\begin{tabular}{ccc} 
& & \\
& Concept achievement $\left(\mathbf{A}_{\mathbf{1}}\right)$ & Direct Instruction $\left(\mathbf{A}_{\mathbf{2}}\right)$ \\
\hline High $\left(\mathrm{B}_{1}\right)$ & $\mathrm{A}_{1} \mathrm{~B}_{1}(14)$ & $\mathrm{A}_{2} \mathrm{~B}_{1}(14)$ \\
\hline Low $\left(\mathrm{B}_{2}\right)$ & $\mathrm{A}_{1} \mathrm{~B}_{2}(14)$ & $\mathrm{A}_{2} \mathrm{~B}_{2}(14)$ \\
\hline Total & 28 & 28 \\
\hline
\end{tabular}

\section{Results and Discussion}

The results of data descriptions on student learning outcomes in the Chemistry Education Study Program Faculty of Teacher Training and Education Halu Oleo University are presented in Table 2.

Table 2. Results of Descriptive Analysis

\begin{tabular}{rrcc}
\hline \multirow{2}{*}{ Mathematic Logic Intelligence (B) } & \multicolumn{2}{c}{ Learning Outcomes (Y) } \\
\cline { 3 - 4 } & & $\begin{array}{c}\text { Concept Achievement } \\
\text { Learning Model }\left(\mathbf{A}_{\mathbf{1}}\right)\end{array}$ & $\begin{array}{c}\text { Direct Learning Model } \\
\left(\mathbf{A}_{\mathbf{2}}\right)\end{array}$ \\
\hline \multirow{3}{*}{ High $\left(\mathrm{B}_{1}\right)$} & $\mathrm{N}$ & 14 & 14 \\
& Average & 85,71 & 65,86 \\
& Standard Deviation & 3,52 & 6,64 \\
\hline \multirow{2}{*}{ Low $\left(\mathrm{B}_{1}\right)$} & $\mathrm{N}$ & 14 & 14 \\
& Average & 64,29 & 72,86 \\
& Standard Deviation & 6,97 & 6,26 \\
\hline & $\mathrm{N}$ & 28 & 28 \\
& Average & 75 & 69,36 \\
& Standard Deviation & 12,18 & 7,27 \\
\hline
\end{tabular}

Table 2 interprets that mathematical logic intelligence affects learning outcomes both using the concept attainment model and the direct learning model. However, in terms of learning outcomes concept attainment model was higher (85.75) than with the direct instructional model (65.86). Furthermore, this difference can be seen from the categorization of the student's mathematical intelligence into two high mathematical intelligence and low 
mathematical intelligence. Therefore, in addition to the use of learning models, the intelligence of an individual, especially in mathematical logic intelligence, needs to be taken into consideration to achieve optimal learning outcomes. Furthermore, to support the descriptive analysis result prerequisite test conducted in the form of normality test, homogeneity, ANOVA test. The results of the data normality test analysis are presented in Table 3

Table 3. Data Normality Test Results Using the Lilliefors Test

\begin{tabular}{cccccc}
\hline No & Group & $\mathbf{N}$ & $\mathbf{L}_{\text {Table }}$ & $\mathbf{L}_{\text {Count }}$ & Conclusion \\
\hline 1 & $\mathrm{~A}_{1}$ & 28 & 0,167 & 0,146 & Normally distributed \\
2 & $\mathrm{~A}_{2}$ & 28 & 0,167 & 0,058 & Normally distributed \\
3 & $\mathrm{~A}_{1} \mathrm{~B}_{1}$ & 14 & 0,237 & 0,212 & Normally distributed \\
4 & $\mathrm{~A}_{1} \mathrm{~B}_{2}$ & 14 & 0,237 & 0,083 & Normally distributed \\
5 & $\mathrm{~A} 2 \mathrm{~B} 1$ & 14 & 0,237 & 0,096 & Normally distributed \\
6 & $\mathrm{~A} 2 \mathrm{~B} 2$ & 14 & 0,237 & 0,063 & Normally distributed \\
\hline
\end{tabular}

Based on Table 3 that all prices $\mathrm{T}_{\text {Count }}<\mathrm{T}_{\text {Table, }}$ which means accepting Ho. Thus, all samples from each analysis group came from populations that normally distributed because the results of the analysis of the normality test found that the data normally distributed. Next, the homogeneity test was then carried out. The purpose of this homogeneity test is to see whether the distribution of the samples used is homogeneous or not. The results of the homogeneity test analysis are presented in Table 4

Table 4. Homogeneity Test

\begin{tabular}{ccccccc}
\hline No & Dk & $\boldsymbol{\alpha}$ & Group & $\boldsymbol{\chi}^{2}$ Count & $\boldsymbol{\chi}^{2}$ Table & Conclusion \\
\hline 1 & 1 & 0.05 & $\mathrm{~A}_{1}$ and $\mathrm{A}_{2}$ & 1,889 & 3,841 & Homogeneous \\
2 & 3 & 0.05 & Four Cell & 6,63 & 7,81 & Homogeneous \\
\hline
\end{tabular}

Table 4 shows that all the sample data presented are homogeneous. It indicates that the cognitive abilities of the data used have characters that are not much different from one individual to another or the abilities of each individual are almost the same. Furthermore, to see the effect of achievement and mathematical intelligence concepts to the learning outcomes displayed in Table 5. At this stage, the data analysed using 2-way analysis of variance (ANOVA 2-way). The results of data analysis are interpreted in Table 5.

Table 5. Results of Analysis Variance of 2 Way (ANOVA 2-Way)

\begin{tabular}{ccccrrrr}
\hline Source Variance & \multirow{2}{*}{ Db } & \multirow{2}{*}{ JK } & \multirow{2}{*}{ RJK } & \multirow{2}{*}{ F $_{\text {Count }}$} & \multicolumn{2}{c}{$\mathbf{F}_{\text {Table }}$} \\
\hline Inter Columns & 1 & 445,79 & 445,79 & 12,362 & $*$ & 4,03 & 7,15 \\
\hline Inter row & 1 & 728,64 & 728,64 & 20,206 & $*$ & 4,03 & 7,15 \\
\hline Interaction & 1 & 2828,64 & 2828,64 & 78,442 & $* *$ & 4,03 & 7,15 \\
\hline Indeep & 52 & 1875,14 & 36,06 & & & & \\
\hline Total Reduction & 55 & 5878,21 & & & & & \\
\hline Note: $*$ : Significant; $* *$ & $=$ Very significant & & & & & \\
\hline
\end{tabular}

Based on Table 5 shows that the (1) $\mathrm{F}_{\text {Count }}(12.362)>\mathrm{F}_{\text {Table }}(4.03)$ it means that there are differences in student learning outcomes between groups of taught the concept attainment model $\left(\mathrm{A}_{1}\right)$ with groups of students taught using a direct learning model $\left(\mathrm{A}_{2}\right)$; (2) $\mathrm{F}_{\text {Count }}$ $(78,442)>\mathrm{F}_{\text {Table }}(4,03)$ which means that there is an interaction effect $(\mathrm{A} \times \mathrm{B} \neq 0)$ significant between learning models and mathematical logic intelligence to study introductory chemistry 
results. Based on the analysis, it shows that there is the influence of the interaction between the two variables. Furthermore, because there is a significant interaction effect between learning models and logical-mathematical intelligence on learning outcomes of introductory chemistry, then tested further by using Tukey test in which reject $\mathrm{H}_{0}$, if $\mathrm{Q}_{\text {Count }}>\mathrm{Q}_{\text {Table }}$. Tukey test results obtained from that: the results of calculations by Tukey's test at the group of students high intelligence mathematical logic indicates that $\mathrm{Q}_{\text {Count }}(12,37)>\mathrm{Q}_{\text {Table }}(4,04)$, therefore $\mathrm{H}_{0}$ is rejected, it means there is a difference in learning outcomes in chemistry for groups of students high logical-mathematical intelligence between groups of students taught with the concept attainment model $\left(\mathrm{A}_{1} \mathrm{~B}_{1}\right)$ with groups of students taught using a direct learning model $\left(\mathrm{A}_{2} \mathrm{~B}_{1}\right)$.

The results of calculations by Tukey's test at the group of students low-mathematical intelligence indicates that $\mathrm{Q}_{\text {Count }}(-5,34)<\mathrm{Q}_{\text {Table }}(-4,04)$, therefore $\mathrm{H}_{0}$ is rejected, it means there is a difference in learning outcomes in Chemistry for groups of students low logicalmathematical intelligence between groups of students taught with the concept attainment model $\left(\mathrm{A}_{1} \mathrm{~B}_{2}\right)$ with groups of students taught using a direct learning model $\left(\mathrm{A}_{2} \mathrm{~B}_{2}\right)$

The results of the calculation of covariance analysis show that $\mathrm{F}_{\text {Count }}(12,362)>\mathrm{F}_{\text {Table }}$ $(4,03)$ which means that there are differences in introductory chemistry learning outcomes between groups of students taught by the concept attainment model $\left(\mathrm{A}_{1}\right)$ with groups of students taught using a direct learning model $\left(\mathrm{A}_{2}\right)$. Based on the descriptive analysis, the learning outcomes of students taught by the concept achievement learning model have an average of 75 . In contrast, the student learning outcomes that learned by direct instruction has an average of 69.36. It explains that the learning outcomes of students taught with the concept attainment model are higher when compared to the learning outcomes of students acquainted with the direct learning model.

The concept attainment model is a flow of constructivism learning theory that focuses on developing learners' ability to construct their new knowledge through the process to synthesize knowledge and experience of old and new. In addition, the concept attainment model is based on the view that learners or students build their understanding of the topics studying rather than recording lessons in a form that is systematically arranged (Sumartini, 2015; Aulia, 2018). In the concept attainment model, students are designed to distinguish the good examples from the various categories presented, analyze concepts, develop concepts, and acquire ideas.

According to Perini et al. (2018); Sukardjo \& Salam (2020) the concept attainment model is a strategy that allows students to explore critical concepts actively and deeply, students construct their understanding from 'bottom-up', test and perfect understanding. Concept and its critical nature until it becomes permanent. In other words, in the concept attainment model students construct their knowledge, test, excellent conceptual understanding, analyze concepts, and make concept understanding relatively permanent. It is supported by Bhargava (2016); Parson \& Taylor (2011) research found that students are more motivated and ready to learn through the concept attainment model. It means that students taught with the concept attainment model are better preparing to construct their understanding so that it is relatively permanent compared to deductive learning models such as direct learning models.

As a result, the learning outcomes of students taught with the concept attainment model (CAM) will be higher than the learning outcomes of students taught with the direct learning model. It informs the concept attainment model is very suitable when applied in introductory chemistry learning. For example, students compare the properties of one element with another, study its characteristics, study its use, and predict its reactivity, in that students can predict what happens if one is wrong. In this lesson, students will try to incorporate facts, concepts, and generalizations into one building of systematic knowledge, students are 
expected to understand the relationship between these topics is supporting by the expertise and experience they have previously.

In contrast to the direct learning model, the direct learning model lecturers delivering course material directly, step by step. In this direct learning model, the role of the lecturer is more dominant so that the lecturer is the only source of information in learning (Wijaya et al., 2012; Merta, 2013). While the involvement of students in the direct instructional model is significantly less or passive as the direct learning process, students are limited to activities receive, view, observed, understand what was, and concluded the subject matter presented directly (Fatmawati et al., 2019; Marheni \& Suardana, 2017; Hunaidah et al. 2019). Format direct learning model is a lecturer delivering course topic structured in a way to explain concepts and procedures, to check student understanding, the lecturer provides guided exercises and independent exercises. Learning with the direct learning model does not facilitate the students to find their knowledge based on experience, quite wait for the information conveyed by lecturers for then are required to understand (Setyono, 2014).

In addition, the concept attainment model encourages students to build their knowledge actively by connecting facts, rules, ideas they already have with new information they get and then proceed to construct a hypothesis and make conclusions through scientific procedures (Anggraeni, 2013). It lines with what Mayer (2012) stated the concept achievement model includes students who apply inductive reasoning to determine the teacher's idea by examining several positive and negative examples of the concept. The concept attainment model involves students applying inductive reasoning to determine the ideas presented by the teacher by examining positive and negative examples of concepts. Meanwhile, Agustina et al. (2016) write that the Concept Attainment Model (CAM) can enhance the activity of students in the learning process. In addition, CAM has a positive effect on learners' attitudes. The same thing was written by Nainggolan \& Derlina (2017) that the concept achievement model could provide maximum results for students in learning new concepts, and guides students to reconstruct the learning process using examples then conclude so that a new concept is generated.

In contrast to the students that learned by the direct learning model, it tends to be passive and less likely to facilitate students to find their knowledge based on experience. Thus, the theory and facts are very appropriate that the learning outcomes of introductory chemistry among students who learn with the learning model of concept attainment are higher than students who learn using the direct learning model after controlling for initial abilities.

Based on Table 5 explains that $\mathrm{F}_{\text {Count }}(78,442)>\mathrm{F}_{\text {Table }}(4,03)$ it means that there is an interaction effect $(\mathrm{A} \times \mathrm{B} \neq 0$ ) significant between learning models and mathematical logic intelligence to study introductory chemistry results. The influence of the interaction between the learning model (A) and logical-mathematical intelligence (B) on learning outcomes (Y), can be visually explained in Figure 1. Based on Figure 1, it found that the contrast to the students that learned by direct learning model intends to be passive and less likely to facilitate students to find their knowledge based on experience chemistry learning outcomes of students taught with the concept achievement learning model of students have high mathematical, logical intelligence are connected with a straight line on the introductory chemistry learning outcomes. The concept attainment model students low logicalmathematical intersects with a line that connects the learning outcomes of introductory chemistry with direct learning models in groups of students high logical-mathematical intelligence and introductory chemistry learning outcomes that are taught using direct learning models in a group of students low logical-mathematical intelligence. 


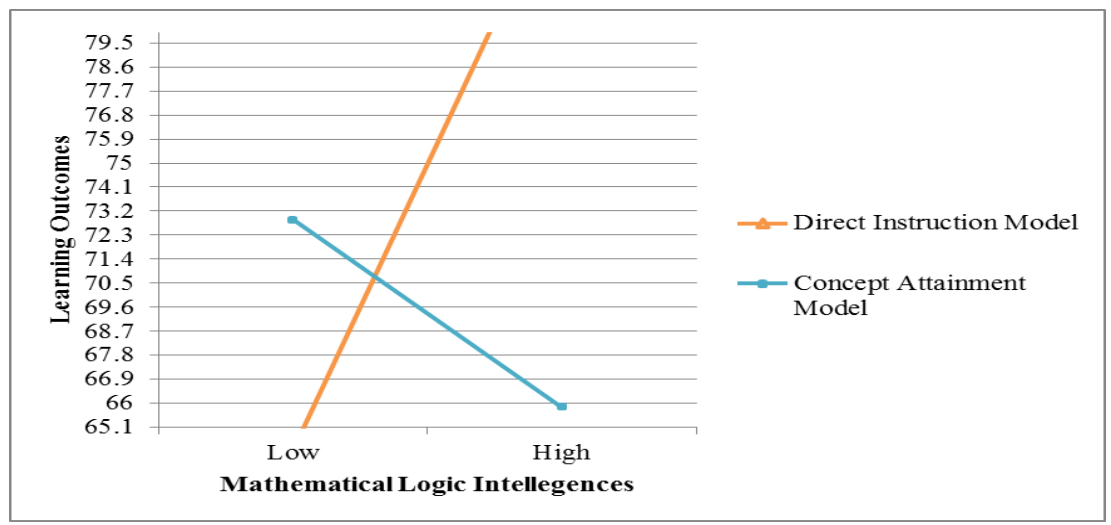

Figure 1. The Effect of the Interaction Between Learning Model and Mathematical Logic Intelligence towards Learning Models

It indicates that both descriptively and visually illustrate that there is an interaction effect between learning models and mathematical, logical intelligence on introductory chemistry learning outcomes. In other words, learning models and mathematical logic intelligence on each other and both affect the results of introductory study chemistry. These results are supported from studies conducted using the Advanced Test calculations by Tukey's test that the group of students high mathematical logic intelligence represent that $\mathrm{Q}_{\text {Count }}(12,37)>\mathrm{Q}_{\text {Table }}(4,04)$ so that $\mathrm{H}_{0}$ is rejected, It means there are differences in learning outcomes for a group of students high logical-mathematical intelligence between groups of students that learned the concept attainment model $\left(\mathrm{A}_{1} \mathrm{~B}_{1}\right)$ with groups of students taught using a direct learning model $\left(\mathrm{A}_{2} \mathrm{~B}_{1}\right)$.

For a group of students with high logical-mathematical intelligence, the learning outcomes of students taught with the concept attainment model have an average of 85.71. While the learning outcomes students taught using the direct learning model have an average of 65,86 . Thus, it can be concluded that the learning outcomes that are taught with the concept attainment model are higher than those taught by the direct learning model for groups of students with high logical-mathematical intelligence.

Students with high logical-mathematical intelligence tend to enjoy learning activities relating to the material relating to the matter or material that requires high critical thinking skills such as chemical kinetics, colligative properties, acid and alkaline $\mathrm{pH}, \mathrm{pH}$ buffer solution, $\mathrm{pH}$ hydrolysis, and solubility results of solubility and redox reaction equation. For example, the student should be able to: (a) calculate the concentration of the solution, (b) determine the type of saline and alkaline, (c) describes the reaction of ionization of weak bases and salts are soluble, and (d) completing mathematical equations. Therefore, the potential of mathematical logic intelligence possessed by students is significant because it can facilitate students to learn the material relating to the numbers or material that requires a very high understanding.

Learning that applies the concept achievement model by the characteristics of the topic presented, namely kinetics, solutions, and redox reaction equations that can foster logical thinking skills, develop problem-solving skills, use mathematical operations and analyze causal relationships. Thus, the student learning outcomes that learned the concept attainment model higher than student learning outcomes that learned by direct learning model for students who have high intelligence mathematical logic. It is because of the learning process with the direct learning model, a more dominant role of faculty, students tend to be less active and more notes. One of the weaknesses of the direct learning model is less motivating the students to be actively involved in learning. It means that students who have high logical intelligence are more suitable for learning the concept attainment model compared to the direct learning model. The concept learning model involves students using critical thinking 
and metacognition skills. The concept Attainment model definition is an educational model that encourages inductive thought processes. It means that the concept attainment model is an inductive learning model suitable for the characteristics of students who have high logicalmathematical intelligence (Hramik \& Hudson, 2011; Slavin, 2011; McDonald, 2015).

The results of the calculation of the Advanced Test with the Tukey test in the group of students' low logical-mathematical intelligence indicate that $\mathrm{Q}_{\text {Count }}(-5,34)<\mathrm{Q}_{\text {Table }}(-4,04)$, so $\mathrm{H}_{0}$ is rejected. It means that there is a difference in learning outcomes in Chemistry for groups of students with low logical-mathematical intelligence, between groups of students taught with the concept attainment model $\left(\mathrm{A}_{1} \mathrm{~B}_{2}\right.$ with groups of students taught using a direct learning model $\left(\mathrm{A}_{2} \mathrm{~B}_{2}\right)$. To find out which one higher can be seen from the average of the results of learning. For a group of students who have low logic-mathematical intelligence, student learning outcomes that learned with the concept attainment model has an average of 64.29, while learning outcomes students that learned by the direct learning model has an average of 72,86 .

Thus it can be revealed that student learning outcomes that are taught with the concept attainment model are lower than those taught by the direct learning model for groups of students low logical-mathematical intelligence. It is because the characteristics of students low logical-mathematical intelligence depend more on the direction and explanation of the lecturer in the learning process. Students' low logical-mathematical intelligence in the learning process with the direct learning model benefit more because the learning model material will be accepted directly without having to construct new knowledge. While students with high logical-mathematical intelligence intend to be active and like activities and exploratory will then become saturated, lazy, and unmotivated in the learning process, so the impact on learning outcomes obtained.

Findings from analysis aligned with that proposed by Gersten et al. (2009; Zhang (2017) that direct instruction make learners with learning disabilities more successful. Direct learning is more effective for students who have learning disabilities. It means that the lower the ability of learners exploring more effective learning knowledge directly applicable. In other words, students' low logical-mathematical intelligence will be more effectively taught with the direct learning model compared to the concept achievement learning model. In the student learning outcomes that learned the concept attainment model of students is lower than that understood by the direct learning model for students' low intelligence mathematical logic.

\section{Conclusion}

From the results of the analysis and findings, it can be concluded that: (1) The student learning outcomes taught with the concept attainment model are higher than those taught by direct learning. (2) There is an interaction effect between learning models and logicalmathematical intelligence on introductory chemistry learning outcomes. (3) Students of student learning outcomes that learned the concept attainment model higher than that known by direct learning model for the group of student's high intelligence mathematical logic. (4) Student learning outcomes learned by the concept attainment model are lower than those learned by the direct learning model for the group of student's low intelligence mathematical logic.

\section{References}

Afifah, N. (2019). Penerapan Model Pembelajaran Pencapaian Konsep Untuk Meningkatkan Pemahaman Konsep. Numeracy Journal, 6(2).

Agustin, P. R., \& Yuliastuti, R. (2019). Penerapan Model Pembelajaran Pencapaian Konsep dengan Pendekatan Kontekstual untuk Meningkatkan Pemahaman Konsep Matematika 
Siswa. Jurnal Silogisme: Kajian Ilmu Matematika Dan Pembelajarannya, 3(2), 63-70. https://doi.org/10.24269/silogisme.v3i2.1270

Agustina, R., Huzaifah, S., \& Dayat, E. (2016). Pengaruh Penerapan Model Pencapaian Konsep (Concept Attainment Model) Terhadap Hasil Belajar Peserta Didik Pada Materi Jamur Kelas X SMA Negeri 2 Inderalaya Utara. Jurnal Pembelajaran Biologi: Kajian Biologi Dan Pembelajarannya, 3(2). https://doi.org/10.36706/fpbio.v3i2.4684

Anggraeni, Y. (2013). Tingkat Keberhasilan Program Corporate Social Responsibility "Water Access - Sanitation and Hygiene" PT Aqua Golden Mississippi Citereup [Institut Pertanian Bogor]. http://repository.ipb.ac.id/handle/1234 56789/66073

Aulia, D. (2018). Pengaruh Penerapan Model Pencapaian Konsep Terhadap Kemampuan Berpikir Kritis Matematika Siswa Man 2 Model Pekanbaru (Doctoral dissertation, Universitas Islam Negeri Sultan Syarif Kasim Riau).

Barrientos-Fernández, A., Sánchez-Cabrero, R., Arigita-García, A., Manoso-Pacheco, L., Pericacho-Gómez, F. J., \& Novillo-López, M. Á. (2019). Measurement of different types of intelligence (general, verbal vs. non-verbal, multiple), academic performance and study habits of secondary students at a Music Integrated Centre. PMC Journal, 25. https://doi.org/10.1016/j.dib.2019.104124

Bhargava, R. (2016). Effect of concept attainment model on achievement in social sciences. International Journal of Science and Research, 5(5), 699-701. https://doi.org/10.21275/v5i5.7051604

Darling-Hammond, L., Flook, L., Cook-Harvey, C., Barron, B., \& Osher, D. (2020). Implications for the educational practice of the science of learning and development. Applied Developmental Science, 24(2), 97-140. https://doi.org/10.1080/10888691.2018.1537791

Fathurrohman, M. (2015). Model-Model Pembelajaran. Ar-Ruzz Media. Retrieved from.

Fatmawati, F., Sukariasih, L., Fayanto, S., \& Retnawati, H. (2019). Investigating the Effectiveness of Inquiry Learning and Direct Learning Models Toward Physics Learning. Advances in Social Science, Education and Humanities Research. https://doi.org/10.2991/iconprocs-19.2019.54

Fjortfoft, A., McLaughlin, T., Derby, M., Everson, M., \& Johnson, K. (2014). The effects of two direct instruction teaching procedures to basic skills to two students with disabilities. Multidisciplinary Journal of Educational Research, 4(2), 151-181. https://doi.org/10.4471/remie.2014.09

Gersten, R., Beckmann, S., Clarke, B., Foegen, A., Marsh, L., Star, J. R., \& Witzel, B. (2009). Assisting Students Struggling with Mathematics: Response to Intervention (RtI) for Elementary and Middle Schools. NCEE 2009-4060. What Works Clearinghouse.

Hattie, J. A., \& Donoghue, G. M. (2016). Learning strategies: A synthesis and conceptual model. Science of Learning, 1(1), 1-13. https://www.nature.com/articles/npjscilearn201613

Hunaidah, M., Armin, A., \& Fayanto, S. (2018, May). Penerapan model pembelajaran Predict-Observe-Explain (POE) dengan metode demonstrasi untuk meningkatkan aktivitas dan hasil belajar IPA Fisika materi pokok kalor Kelas VII2 SMP Negeri 15 Kendari. In Quantum: Seminar Nasional Fisika, dan Pendidikan Fisika (pp. 293-298).

Kauts, S., \& Kaur, N. (2019). Effectiveness of concept attainment model on academic achievement in science in relation to cognitive styles among ix grade students. 
International Journal Od Scientific and Reviews, 8(1), 1773-1789. https://www.semanticscholar.org/paper/Effectiveness-of-Concept-Attainment-Modelon-in-in-Kauts-Kaur/4245df4ab1a7c4915ab516ac73e3c97e3b8a163b

Kawuri, M. Y. R. T., Ishafit, I., \& Fayanto, S. (2019). Efforts to improve the learning activity and learning outcomes of physics students with using a problem-based learning model. IJIS Edu: Indonesian Journal of Integrated Science Education, 1(2), 105-114. http://dx.doi.org/10.29300/ijisedu.v1i2.1957

Khalil, M. K., \& Elkhider, I. A. (2016). Applying learning theories and instructional design models for effective instruction. Advances in Physiology Education, 40(2), 147-156. https://doi.org/10.1152/advan.00138.2015

Khatabyeh. (2011). Multiple intelligences of students at Jordanian universities 1-13. Journal of International Education Research, 7(4), 1-13. https://eric.ed.gov/?id=EJ948524

Killian, M., \& Bastas, H. (2015). The effects of an active learning strategy on students' attitudes and students' performances in introductory sociology classes. Journal of the Scholarship of Teaching and Learning, 15(3), 53-67. https://doi.org/10.14434/josotl.v15i3.12960

Kumar, A., \& Mathur, M. (2013). Effect of Concept Attainment Model on Acquisition of Physics Concepts. Universal Journal of Educational Research, 1(3), 165-169. https://doi.org/10.13189/ujer.2013.010304

Latchanna, G., \& Swarnalatha, K. (2016). Effect Of Concept Attainment And Inquiry Training Model In Teaching Biological Science At Secondary Level. MIER Journal of Educational Studies, Trends and Practices, 6(1). http://www.mierjs.in/ojs/index.php/mjestp/article/view/111/111

Marheni, N. P., \& Suardana, I. N. (2017). Pembelajaran Inkuiri Terbimbing Berbasis Budaya Lokal pada Pembelajaran Sains Kimia SMP. Jurnal Matematika, Sains, Dan Pembelajarannya, 8(2), 87-100.

Mayer, J. R. (2012). Effects of using the concept attainment model with inductive reasoning with high school biology students.

McCormick, N. J., Clark, L. M., \& Raines, J. M. (2015). Engaging students in critical thinking and problem solving: A brief review of the literature. Journal of Studies in Education, 5(4), 100-113. https://doi.org/10.5296/jse.v5i4.8249

Merta, L. M. (2013). Pengaruh Model Pembelajaran Kontekstual terhadap Penguasaan Konsep Koloid dan Sikap Ilmiah Siswa. Jurnal Pendidikan Dan Pengajaran, 46(1). http://dx.doi.org/10.23887/jppundiksha.v46i1.1688

Nainggolan, A. P., \& Derlina, D. (2017). Pengaruh Model Pembelajaran Pencapaian Konsep (Concept Attainment) Terhadap Hasil Belajar Siswa Pada Materi Pokok Pengukuran. Jurnal Ikatan Alumni Fisika Universitas Negeri Medan, 3(2), 1-6. https://doi.org/10.24114/jiaf.v3i2.10726

Nondo, F. T., Fihrin, F., \& Ali, M. (2016). Penerapan model pembelajaran pencapaian konsep untuk peningkatan pemahaman konsep fisika pada siswa kelas X SMA Negeri 8 Palu. JPFT (Jurnal Pendidikan Fisika Tadulako Online), 4(1). https://core.ac.uk/download/pdf/291816170.pdf

Novitasari, A., Ilyas, A., \& Amanah, S. N. (2017). Pengaruh model pembelajaran inkuiri terbimbing terhadap keterampilan proses sains peserta didik pada materi fotosintesis 
kelas XII IPA di SMA Yadika Bandar Lampung. Biosfer: Jurnal Tadris Biologi, 8(1), 91-104. https://doi.org/10.24042/biosf.v8i1.1267

Osterlind, S, J. (2002). Constructing test items: multiple-choice, constructed-response, performance, and other formats. Kluwer Academic Publishers.

Pérez, P. M., Costa, J. L. C., \& Corbí, R. G. (2012). An explanatory model of academic achievement based on aptitudes, goal orientations, self-concept and learning strategies. The Spanish Journal of Psychology, 15(1), 48-60. https://doi.org/10.5209/rev_sjop.2012.v15.n1.37283

Rahmi, F., \& Harahap, M. B. (2013). Pengaruh Model Pembelajaran Pencapaian Konsep Dengan Menggunakan Peta Pikiran Sebagai Upaya Mengurangi Miskonsepsi Siswa. INPAFI (Inovasi Pembelajaran Fisika), 1(2). https://doi.org/10.24114/inpafi.v1i2.2013

Said, A. (2017). 95 Strategi Mengajar Multiple Intelligences. Prenada Media.

Setyono, D. E. D. I. K. (2014). Perbandingan Model Pembelajaran Langsung Dan Model Pembelajaran Kooperatif Terhadap Hasil Belajar Bounce Pass Pada Permainan Bola Basket (Studi Pada Siswa SMPN 1 Kesamben Kab. Jombang Kelas VIII). Urnal Pendidikan Dlahraga Dan https://jurnalmahasiswa.unesa.ac.id/index.php/jurnal-pendidikanjasmani/article/view/10033/9827

Siregar, S. (2012). Meningkatkan Hasil Belajar Matematika Siswa pada Materi Pokok Peluang Melalui Model Pembelajaran Pencapaian Konsep di SMA Negeri 4 Padangsidimpuan. Edumatica: Jurnal Pendidikan Matematika, 2(02). https://doi.org/10.22437/edumatica.v2i02.843

Situmorang, A. S., \& Siahaan, F. B. (2019). Desain Model Pencapaian Konsep Terhadap Minat Belajar Mahasiswa FKIP UHN. Jurnal Penelitian Bidang Pendidikan, 25(1), 5561. https://doi.org/10.24114/jpbp.v25i1.15533

Slavin, R. E. (2011). Instruction Based on Cooperative Learning. In R. E. Mayer \& P. A. Alexander (Eds.), Handbook of Research on Learning and Instruction (pp. 344-360). Taylor \& Francis.

Sood, V. (2013). Effect of mastery learning strategies on concept attainment in geometry among high school students. International Journal of Behavioural Social and Movement Sciences, 2(2), 144-155. www.ijobsms.in

Sugiyono. (2008). Metode penelitian pendidikan:(pendekatan kuantitatif, kualitatif dan $R \&$ $D)$. Alfabeta.

Suleman, A. M. (2016). Concept Attainment Teaching Methodology (CATM)--An Effective Approach for Training Workers on Chemicals Health Hazards. Universal Journal of Educational Research, 4(11), 2677-2685. https://doi.org/10.13189/ujer.2016.041122

Wijaya, I. K. W. B., Kirna, I. M., \& Suardana, I. N. (2012). Model demonstrasi interaktif berbantuan multimedia dan hasil belajar IPA aspek kimia siswa SMP. Jurnal Pendidikan Dan Pengajaran, 45(1). hhttp://dx.doi.org/10.23887/jppundiksha.v45i1.1788

Zhang, D. (2017). Effects of Visual Working Memory Training and Direct Instruction on Geometry Problem Solving in Students with Geometry Difficulties. Learning Disabilities: A Contemporary Journal, 15(1), 117-138. Effects of Visual Working Memory Training and Direct Instruction on Geometry Problem Solving in Students with Geometry Difficulties. 